\title{
Effect of Cultivation and Soil Tillage Systems on the Microbial Biomass in Castor Bean Crop at the Irecê Plateau, Bahia
}

\author{
Camila Brasil Dias ${ }^{1}$, Eduardo Gross ${ }^{2}$, Arlicélio de Queiroz Paiva ${ }^{2}$, Luciano da Silva Souza ${ }^{3}$, \\ Carlos Alberto da Silva Ledo ${ }^{4} \&$ Francisco Alisson da Silva Xavier ${ }^{4}$ \\ ${ }^{1}$ Postgraduate Program in Crop Production, Universidade Estadual de Santa Cruz, Bahia, Brazil \\ ${ }^{2}$ Departamento de Ciências Agrárias e Ambientais, Universidade Estadual de Santa Cruz, Bahia, Brazil \\ ${ }^{3}$ Universidade Federal do Recôncavo da Bahia, Bahia, Brazil \\ ${ }^{4}$ Embrapa Mandioca e Fruticultura, Bahia, Brazil \\ Correspondence: Eduardo Gross, Departamento de Ciências Agrárias e Ambientais, Universidade Estadual de \\ Santa Cruz, Rod. Jorge Amado, Km 16 Ilhéus, BA, 45662-900, Brazil. Tel: 55-733-680-5191; Fax: \\ 55-733-680-5254. E-mail: egross@uesc.br
}

Received: November 29, 2018

doi:10.5539/jas.v11n4p341
Accepted: January 22, 2019 Online Published: March 15, 2019

URL: https://doi.org/10.5539/jas.v11n4p341

\begin{abstract}
Inadequate soil management alters the microbiological attributes of the soil, causing reduction in microbial biomass and activity. Microbial biomass is the living and active part of the soil and can serve as an indicator of changes in the quantity of due to changes in land use. This study aimed to evaluate the effect of intercropping and soil tillage systems on the microbial biomass in castor bean-based crop in the Irecê Plateau, Bahia, Brazil. The experiment was carried out on an eutrophic Haplic Cambisol with clay texture in the Mata Verde Farm of Alto do Quindinho, municipality of São Gabriel, Irecê Plateau, Bahia, Brazil. Six intercropping systems were evaluated including solely castor bean (control) and castor bean intercropped with each of the castor bean cake, common bean, pigeon pea, corn, and gliricidia. Plowing + harrowing and subsoiling were the two soil tillage techniques associated to the intercropping systems. $\mathrm{C}$ and $\mathrm{N}$ contents in microbial biomass (Cmic and Nmic), soil basal respiration and metabolic quotient were determined in soil samples collected from the $0-10$ and 10-30 $\mathrm{cm}$ layers. The different soil management systems influenced microbial biomass and activity, and the most suitable conditions for soil microbiota occurred in the soil tillage system with subsoiling. In the semi - arid condition, at $0-10 \mathrm{~cm}$ depth, the castor bean + castor bean cake crop system promoted an increase of Cmic content, and the castor + gliricidia system increased Nmic content, both under soil tillage with subsoiling.
\end{abstract}

Keywords: microbiota, semi-arid region, management

\section{Introduction}

The region of Irecê is located in Northwestern Bahia, Brazil, and is considered as one of the country largest producer of castor bean. Its soils have high natural chemical fertility, but inadequate soil management, associated with water deficit, high temperatures and low physical quality of soils, contribute to low agricultural production in the region.

In Brazil, the Bahia state is the largest castor bean producer, with about 51,487 ha cultivated and a production of 33,541 tons in 2014 , which corresponded to $89 \%$ of the national production and $95 \%$ of the production in the Northeast region (IBGE, 2016). However, yields in Bahia are lower than the national mean, a situation that has led research institutions to conduct studies to increase the production potential of castor bean in the mesoregion of Irecê, which is the main center of castor bean production in the country.

Agriculture modernization is closely related to the mechanization of field operations. One of most important and negative impacts of mechanization in agricultural systems is the increase of soil compaction due to machinery traffic (Roboredo et al., 2010). Mechanical soil tillage directly influences the physical and biological properties of the soil. The turning of the soil for the establishment of an agricultural crop causes imbalance in the microbiota, which affects nutrient cycling in the soil (Lisboa et al., 2012). Microbial biomass is considered as a good indicator to express the level of soil quality (Islam \& Weil, 2000). Analysis of C and N contents in the microbial biomass in combination to soil basal respiration measurements are normally used for this purpose. 
Joint analysis of these parameters generates an index called metabolic quotient $\left(q \mathrm{CO}_{2}\right)$. This index relates microbial respiration with the magnitude of its biomass, providing an analysis of the efficiency of microorganisms at transforming soil organic C into microbial-C (Anderson \& Domsch, 1993; Alves et al., 2011).

The amounts of $\mathrm{N}$ immobilized in the biomass can reach very high values, above $100 \mathrm{~kg} \mathrm{ha}^{-1}$ (Anderson \& Domsch, 1980). The $\mathrm{N}$ retained in the biomass is released as the microorganisms die and are mineralized by the remaining population, which is the reason why in soils subjected to environmental stresses most of the $\mathrm{N}$ mineralized can be of microbial origin (Marumoto et al., 1982). Therefore, microbial biomass acts as a $\mathrm{N}$ buffer of the soil, since it controls its availability through processes of mineralization and immobilization. In different soil management systems, the microbiota undergoes different stimuli due to the composition of the residues of plant species and to soil tillage methods. This results in differences in microbial activity, $\mathrm{N}$ immobilization-mineralization ratio and residue decomposition rates.

The effect of cover plants and tillage systems on the improvement of soil biological attributes should be quantified regionally and for each production system, because it depends on soil texture and mineralogy, relief and on the conditions of temperature and moisture (Cunha et al., 2011). Thus, this study aimed to evaluate the effect of intercropping systems and soil tillage techniques on microbial biomass in castor bean crop in the Irecê Plateau, Bahia, Brazil.

\section{Materials and Methods}

The experiment was carried out in an area of the Mata Verde farm, in Alto do Quindinho, municipality of São Gabriel, Irecê Plateau, Bahia. UTM 24 L 182102 E and 8764029 S at an elevation 784 m a.s.l. The climate was semi-arid. The average annual rainfall was $583 \mathrm{~m}$ and the average temperature $23.3{ }^{\circ} \mathrm{C}$ The soil was predominantly Tb eutrophic Haplic Cambisol (Embrapa, 2006).

Plots with $900 \mathrm{~m}^{2}$ area $(30 \mathrm{~m} \times 30 \mathrm{~m})$ were delimited and the spacing adopted for the castor bean crop was $3.0 \mathrm{~m}$ $\times 1.0 \mathrm{~m}$, totaling 300 plants per plot. The cultivar 'BRS 149 Nordestina' was used, which has medium size, semi-dehiscent fruits and black seeds with $48.9 \%$ oil content. Its mean yield was $1,500 \mathrm{~kg} \mathrm{ha}^{-1}$ and its cycle lasts 250 days (Freire et al., 2007). Six castor bean intercropping systems were evaluated including (1) castor bean (control), (2) castor bean + castor bean cake, (3) castor bean + common bean, (4) castor bean + pigeon pea, (5) castor bean + corn, and (6) castor bean + Gliricidia (Gliricidia sepium) under two different soil tillage systems i.e. (1) conventional tillage with plowing + harrowing and (2) soil tillage with subsoiling before castor bean planting. Subsoiling was carried out with a subsoiler composed of three shanks spaced by $0.50 \mathrm{~m}$ and $0.05 \mathrm{~m}$ wide point, with $0.50 \mathrm{~m}$ working depth. The experiment was arranged in a split-plot design, in randomized blocks where soil tillage methods were the main plots and intercropping the subplots.

The soil presented the physicochemical characteristics contained in Table 1.

Table 1. Physic and chemical characteristics of the soils in the experimental area

\begin{tabular}{|c|c|c|c|c|c|c|c|c|c|c|c|c|}
\hline Sand & Silt & Clay & $\mathrm{H}_{2} \mathrm{O}$ PWP & Density & $\mathrm{pH}_{\mathrm{H}_{2} \mathrm{O}}$ & Avail P & Avail K & $\mathrm{Al}^{3+}$ & $\mathrm{H}+\mathrm{Al}$ & CEC & BS & Organic matter \\
\hline 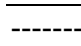 & $\mathrm{g} \mathrm{kg}^{-1}$ & ------ & $--\mathrm{m}^{3} \mathrm{~m}^{-3}$ & $-\mathrm{kg} \mathrm{dm}^{-3}$ & & ----- mg & $\mathrm{dm}^{-3}$----- & (----- & $\mathrm{cmol}_{\mathrm{c}} \mathrm{dm}$ & $-3-\cdots$ & $\%$ & dag $\mathrm{kg}^{-1}$ \\
\hline 235 & 235 & 447 & 0.17 & 1.3 & 6.3 & 4.2 & 104 & 0.0 & 2.2 & 14.5 & 83 & 2.1 \\
\hline
\end{tabular}

Note. $\mathrm{H}_{2} \mathrm{O} \mathrm{PWP}=$ moisture at permanent wilting point, Density $=$ bulk density, Avail $\mathrm{P}=$ available $\mathrm{P}$, Avail $\mathrm{K}=$ available $\mathrm{K}, \mathrm{CEC}=$ cation exchange capacity, $\mathrm{BS}$ = base saturation

Soil temperature was monitored in each soil tillage treatment by copper-constantan thermocouples sensors (Alutal, Votorantim, São Paulo, Brazil) installed at 5, 10, and $20 \mathrm{~cm}$ depth. To monitor soil moisture, CS616 sensors (Campbell Scientific Inc., Utah, USA) were installed in each treatment, which recorded the moisture content integrated over the 0-30 cm layer. Soil temperature and soil moisture sensors were interconnected by a data logger (CR1000, Campbell Scientific Inc., Utah, USA), programmed to take readings every hour and store the data. Table 2 present mean values of soil temperature and volumetric moisture on the sampling days. 
Table 2. Means of soil temperature (Temp) and volumetric moisture $(\theta)$ on the days of soil sampling from 2015 to 2017 in experimental field

\begin{tabular}{|c|c|c|c|c|}
\hline \multirow{3}{*}{ Intercropping systems } & \multicolumn{4}{|c|}{ Tillage systems } \\
\hline & \multicolumn{2}{|c|}{ Plowing + harrowing } & \multicolumn{2}{|c|}{ Subsoiling } \\
\hline & Temp $\left({ }^{\circ} \mathrm{C}\right)$ & $\theta\left(\mathrm{m}^{3} \mathrm{~m}^{-3}\right)$ & Temp $\left({ }^{\circ} \mathrm{C}\right)$ & $\theta\left(\mathrm{m}^{3} \mathrm{~m}^{-3}\right)$ \\
\hline Castor bean (control) & 30.18 & 0.08 & 30.04 & 0.07 \\
\hline Castor bean + common bean & 30.15 & 0.08 & 30.62 & 0.09 \\
\hline Castor bean + gliricidia & 31.01 & 0.07 & 30.98 & 0.06 \\
\hline Castor bean + pigeon pea & 32.43 & 0.07 & 31.12 & 0.06 \\
\hline Castor bean + corn & 30.47 & 0.09 & 30.58 & 0.07 \\
\hline Castor bean + castor bean cake & 30.45 & 0.09 & 30.65 & 0.10 \\
\hline
\end{tabular}

Soil samples for microbiological analysis were collected using a Dutch auger at $0-10 \mathrm{~cm}$ and $10-30 \mathrm{~cm}$ depths. In each plot, nine soil cores were collected to form a composite sample for each depth. Immediately after collection, the composite samples were sieved through a 2-mm mesh, placed in plastic bags, identified and stored in cold chamber at $4{ }^{\circ} \mathrm{C}$ until analysis. Soil sampling was carried out on the days in which soil volumetric moisture contents were below the permanent wilting point $\left(\theta_{\mathrm{PWP}}<0.17 \mathrm{~m}^{3} \mathrm{~m}^{-3}\right)$, precisely on November 15,2015 ; March 30, 2016; November 05, 2016 and April 11, 2017.

Soil microbial biomass was determined by the irradiation-extraction method (Islam \& Weil, 1998), using electromagnetic energy (microwaves) to cause cell lysis in the microorganisms. For each treatment, two subsamples (irradiated and non-irradiated) of $20 \mathrm{~g}$ of soil were used. Samples were irradiated using a microwave oven and the time of irradiation was 90 seconds. For $\mathrm{C}$ extraction, a $0.5 \mathrm{~mol} \mathrm{~L}^{-1} \mathrm{~K}_{2} \mathrm{SO}_{4}$ solution was used. The samples were shaken for one hour in horizontal shaker at $180 \mathrm{rpm}$ and, after half an hour of decantation, the supernatant was filtered using slow quantitative filter paper. For the analysis of $\mathrm{C}$ and $\mathrm{N}$ contents, aliquots of 5 and $20 \mathrm{~mL}$ were collected, respectively. Carbon content on the extracts was determined by wet combustion (Yeomans \& Bremner, 1988) and nitrogen by the Kjeldahl method (Tedesco et al., 1995).

Microbial biomass $\mathrm{C}$ and $\mathrm{N}$ (MB-C and MB-N) contents were calculated using Equations 1 and 2, respectively.

$$
\mathrm{MB}-\mathrm{C}=(\mathrm{Ci}-\mathrm{Cni}) / \mathrm{Kc}
$$

where,

MB-C $=$ Carbon content of soil microbial biomass $\left(\mathrm{mg} \mathrm{kg}^{-1}\right) ; \mathrm{Ci}=$ Carbon content of the irradiated sample (mg $\left.\mathrm{kg}^{-1}\right)$; $\mathrm{Cni}=$ Carbon content of the non-irradiated sample $\left(\mathrm{mg} \mathrm{kg}^{-1}\right) ; \mathrm{Kc}=$ correction factor for the method of irradiation-extraction of carbon from soil microbial biomass (Sparling \& West, 1988), Kc =0.33.

$$
\mathrm{MB}-\mathrm{N}=(\mathrm{Ni}-\mathrm{Nni}) / \mathrm{Kn}
$$

where,

MB-N = Nitrogen content of soil microbial biomass $\left(\mathrm{mg} \mathrm{kg}^{-1}\right) ; \mathrm{Ni}=$ Nitrogen content of the irradiated sample $\left(\mathrm{mg} \mathrm{kg}^{-1}\right) ; \mathrm{Nni}=$ Nitrogen content of the non-irradiated sample $\left(\mathrm{mg} \mathrm{kg}^{-1}\right) ; \mathrm{Kn}=$ correction factor for the method of irradiation-extraction of nitrogen from soil microbial biomass (Brookes et al., 1985) and $\mathrm{Kn}=0.54$.

Soil basal respiration (SBR) was determined by quantifying the carbon dioxide $\left(\mathrm{CO}_{2}\right)$ released in the process of microbial respiration after 10 days of incubation according to Mendonça and Matos (2005). Briefly, $100 \mathrm{~g}$ of each of the soil samples were incubated at $25{ }^{\circ} \mathrm{C}$ in hermetically sealed flasks in the presence of $0.5 \mathrm{~mol} \mathrm{~L}^{-1}$ $\mathrm{NaOH}$ solution $(30 \mathrm{~mL})$. After incubation time, the container was opened and kept for 15 minutes at room temperature. Then, $10-\mathrm{mL}$ aliquots were collected in the $\mathrm{NaOH}$ solution and mixed with $3 \mathrm{~mL}$ of $0.5 \mathrm{~mol} \mathrm{~L}^{-1}$ $\mathrm{BaCl}_{2}$ solution. The solution was titrated with $0.25 \mathrm{~mol} \mathrm{~L}^{-1} \mathrm{HCl}$ after addition of phenolphthalein indicator. SBR was expressed in mg C-CO $\mathrm{kg}^{-1}$ soil $\mathrm{h}^{-1}$. The ratio between SBR and MB-C was used to determine the metabolic quotient $\left(q \mathrm{CO}_{2}\right)$, which expresses the efficiency of microbial biomass at converting soil organic $\mathrm{C}$ to microbial $\mathrm{C}$

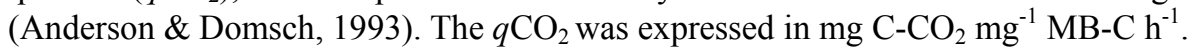

\section{Statistical Analysis}

The data soil microbial biomass $\mathrm{C}(\mathrm{MB}-\mathrm{C})$ and $\mathrm{N}(\mathrm{MB}-\mathrm{N})$, soil basal respiration (SBR), and metabolic quotient $\left(q \mathrm{CO}_{2}\right)$ were subjected to an analysis of variance to evaluate the effect of soil tillage as well as the effect of the intercropping systems. The mean values of the soil tillage techniques were compared by Tukey test at 0.05 probability level to evaluate the effect of soil tillage and the mean values of the intercropping systems were separated using Scott-Knott test at 0.05 probability level. 


\section{Results}

In both layers, the interaction between soil tillage and intercropping systems was significant for MB-C contents (Table 3). In general, soil tillage with subsoiling led to increase in MB-C in comparison to the tillage with plowing and harrowing. This response can be attributed to the greater turning of the soil by the plow and harrow, which accelerates the process of oxidation of soil organic matter causing stress on the microbial biomass.

Table 3. Analysis of variance of data soil microbial biomass (MB-C) and N (N-MB), the basal soil respiration (SBR) and metabolic quotient $\left(q \mathrm{CO}_{2}\right)$

\begin{tabular}{|c|c|c|c|c|c|}
\hline FV (MB-C) & GL & SQ & $\mathrm{QM}$ & $\mathrm{FC}$ & $\mathrm{Pr}>\mathrm{Fc}$ \\
\hline A & 5 & 139587.83 & 27917.567 & 20.397 & 0.0011 \\
\hline Error 1 & 6 & 8212.44 & 1368.7412 & & \\
\hline B & 1 & 174823.57 & 174823.578 & 163.320 & 0.0000 \\
\hline$A * B$ & 5 & 48988.077 & 9797.6154 & 9.153 & 0.0009 \\
\hline Error 2 & 12 & 12845.2129 & 1070.4344 & & \\
\hline $\mathrm{C}$ & 1 & 62173.6931 & 62173.693 & 86.751 & 0.0000 \\
\hline$A^{*} \mathrm{C}$ & 5 & 33904.696 & 6780.939 & 9.461 & 0.0000 \\
\hline $\mathrm{B} * \mathrm{C}$ & 1 & 6727.591 & 6727.59 & 9.387 & 0.0053 \\
\hline$A * B * C$ & 5 & 3492.9578 & 6984.19 & 9.745 & 0.0000 \\
\hline Error 3 & 24 & 17200.544 & 716.68 & & \\
\hline Total & 65 & 507956.6 & & & \\
\hline FV (MB-N) & GL & SQ & $\mathrm{QM}$ & $\mathrm{FC}$ & $\operatorname{Pr}>\mathrm{Fc}$ \\
\hline A & 5 & 180.277 & 36.055 & 76.657 & 0.0000 \\
\hline Error 1 & 6 & 2.8220 & 0.470 & & \\
\hline B & 1 & 0.348715 & 0.348 & 0.817 & 0.3838 \\
\hline$A * B$ & 5 & 94.040323 & 18.8080 & 44.066 & 0.0000 \\
\hline Error 2 & 12 & 5.1121 & 0.4268 & & \\
\hline $\mathrm{C}$ & 1 & 306.5081 & 306.5081 & 366.103 & 0.0000 \\
\hline$A^{*} \mathrm{C}$ & 5 & 36.5842 & 7.3168 & 8.739 & 0.0001 \\
\hline $\mathrm{B}^{*} \mathrm{C}$ & 1 & 4.2533 & 4.253329 & 5.080 & 0.0336 \\
\hline$A * B * C$ & 5 & 21.677344 & 4.3354 & 5.178 & 0.0023 \\
\hline Error 3 & 24 & 20.093217 & 0.8372 & & \\
\hline Total & 65 & 671.7163 & & & \\
\hline FV (RBS) & GL & SQ & QM & $\mathrm{FC}$ & $\operatorname{Pr}>\mathrm{Fc}$ \\
\hline A & 5 & 0.003287 & 0.000657 & 4.307 & 0.0520 \\
\hline Error 1 & 6 & 0.000916 & 0.000153 & & \\
\hline B & 1 & 0.002153 & 0.002153 & 18.951 & 0.0009 \\
\hline$A * B$ & 5 & 0.006543 & 0.001309 & 11.520 & 0.0003 \\
\hline Error 2 & 12 & 0.001363 & 0.000114 & & \\
\hline $\mathrm{C}$ & 1 & 0.046075 & 0.046075 & 527.512 & 0.0000 \\
\hline$A * C$ & 5 & 0.008600 & 0.001720 & 19.691 & 0.0000 \\
\hline $\mathrm{B} * \mathrm{C}$ & 1 & 0.000061 & 0.000061 & 0.702 & 0.4104 \\
\hline$A * B^{*} C$ & 5 & 0.009481 & 0.001896 & 21.709 & 0.0000 \\
\hline Error 3 & 24 & 0.002096 & 0.000087 & & \\
\hline Total & 65 & 0.080575 & & & \\
\hline $\mathrm{FV}\left(\mathrm{qCO}_{2}\right)$ & GL & SQ & $\mathrm{QM}$ & $\mathrm{FC}$ & $\operatorname{Pr}>\mathrm{Fc}$ \\
\hline A & 5 & 2.1087 & 0.421745 & 3.501 & 0.0795 \\
\hline Error 1 & 6 & 0.722723 & 0.120454 & & \\
\hline B & 1 & 2.514283 & 2.514283 & 23.044 & 0.0004 \\
\hline$A * B$ & 5 & 1.999335 & 0.399867 & 3.665 & 0.0303 \\
\hline Error 2 & 12 & 1.309294 & 0.109108 & & \\
\hline $\mathrm{C}$ & 1 & 4.097170 & 4.097170 & 52.603 & 0.0000 \\
\hline$A * C$ & 5 & 0.333413 & 0.066683 & 0.856 & 0.5243 \\
\hline $\mathrm{B}^{*} \mathrm{C}$ & 1 & 0.172009 & 0.172009 & 2.208 & 0.1503 \\
\hline$A * B * C$ & 5 & 0.787321 & 0.157464 & 2.022 & 0.1117 \\
\hline Error 3 & 24 & 1.869331 & 0.077889 & & \\
\hline Total & 65 & 15.91358 & & & \\
\hline
\end{tabular}

Note. A: vegetal cover; B: Soil preparation factor; C: Soil depth; FV: variation factor; V.A.: variable analyzed; GL: degree of freedon; SQ: sum of square; QM: middle square; Fc: Fvalue. 
Table 4. Soil microbial biomass C (MB-C) and N (MB-N), soil basal respiration (SBR), and metabolic quotient $\left(q \mathrm{CO}_{2}\right)$ in the $0-10$ and $10-30 \mathrm{~cm}$ layers as a function of different intercropping systems and soil tillage methods in castor bean crop of 2015-2017

\begin{tabular}{|c|c|c|c|c|c|c|c|c|}
\hline \multirow{3}{*}{ Intercropping system } & \multicolumn{8}{|c|}{ Tillage systems } \\
\hline & \multicolumn{4}{|c|}{ Plowing + harrowing } & \multicolumn{4}{|c|}{ Subsoiling } \\
\hline & MB-C & MB-N & SBR & $q \mathrm{CO}_{2}$ & MB-C & MB-N & SBR & $q \mathrm{CO}_{2}$ \\
\hline & ----- mg & $g^{-1}----$ & $\begin{array}{l}\mathrm{mg} \mathrm{C}-\mathrm{CO}_{2} \\
\mathrm{~kg}^{-1} \text { soil h}^{-1}\end{array}$ & $\begin{array}{l}\mathrm{mg} \mathrm{C}-\mathrm{CO}_{2} \\
\mathrm{~g} \mathrm{Cmic}^{-1} \mathrm{~h}^{-1}\end{array}$ & ------ mg & $\mathrm{rg}^{-1}-$ & $\begin{array}{l}\mathrm{mg} \mathrm{C}-\mathrm{CO}_{2} \\
\mathrm{~kg}^{-1} \text { soil h}^{-1}\end{array}$ & $\begin{array}{l}\mathrm{mg} \mathrm{C}-\mathrm{CO}_{2} \\
\mathrm{~g} \mathrm{Cmic}^{-1} \mathrm{~h}^{-1}\end{array}$ \\
\hline \multicolumn{9}{|l|}{$0-10 \mathrm{~cm}$} \\
\hline Castor bean (control) & $239 \mathrm{bA}$ & $9 \mathrm{cB}$ & $0.12 \mathrm{cA}$ & $0.50 \mathrm{bA}$ & $247 \mathrm{cA}$ & $12 \mathrm{cB}$ & $0.11 \mathrm{cB}$ & $0.44 \mathrm{aA}$ \\
\hline Castor bean + castor bean cake & $272 \mathrm{aB}$ & $14 \mathrm{aA}$ & $0.13 \mathrm{bA}$ & $0.48 \mathrm{bA}$ & $349 \mathrm{aA}$ & $12 \mathrm{cB}$ & $0.09 \mathrm{~dB}$ & $0.26 \mathrm{aB}$ \\
\hline Castor bean + common bean & $236 \mathrm{bB}$ & $14 \mathrm{aA}$ & $0.11 \mathrm{~dB}$ & $0.46 \mathrm{bA}$ & $263 \mathrm{cA}$ & $12 \mathrm{cB}$ & $0.13 \mathrm{bA}$ & $0.49 \mathrm{aA}$ \\
\hline Castor bean + pigeon pea & $286 \mathrm{aA}$ & $14 \mathrm{aA}$ & $0.12 \mathrm{cB}$ & $0.42 \mathrm{bA}$ & $300 \mathrm{bA}$ & $13 \mathrm{bA}$ & $0.14 \mathrm{aA}$ & $0.46 \mathrm{aA}$ \\
\hline Castor bean + corn & $172 \mathrm{cB}$ & $12 \mathrm{bA}$ & $0.14 \mathrm{aA}$ & $0.81 \mathrm{aA}$ & $292 \mathrm{bA}$ & $11 \mathrm{cA}$ & $0.13 \mathrm{bB}$ & $0.44 \mathrm{aB}$ \\
\hline Castor bean + gliricidia & $270 \mathrm{aB}$ & $13 \mathrm{aB}$ & $0.11 \mathrm{dA}$ & $0.41 \mathrm{bA}$ & $317 \mathrm{bA}$ & $15 \mathrm{aA}$ & $0.11 \mathrm{cA}$ & $0.35 \mathrm{aA}$ \\
\hline \multicolumn{9}{|l|}{$10-30 \mathrm{~cm}$} \\
\hline Castor bean (control) & $163 \mathrm{cB}$ & $7 \mathrm{bB}$ & $0.14 \mathrm{bA}$ & $0.86 \mathrm{aA}$ & $259 \mathrm{bA}$ & $9 \mathrm{bA}$ & $0.15 \mathrm{aA}$ & $0.58 \mathrm{aA}$ \\
\hline Castor bean + castor bean cake & $274 \mathrm{aB}$ & $11 \mathrm{aA}$ & $0.15 \mathrm{bA}$ & $0.55 \mathrm{aA}$ & $321 \mathrm{aA}$ & $11 \mathrm{aA}$ & $0.16 \mathrm{aA}$ & $0.50 \mathrm{aA}$ \\
\hline Castor bean + common bean & $181 \mathrm{cB}$ & $11 \mathrm{aA}$ & $0.15 \mathrm{bA}$ & $0.83 \mathrm{aA}$ & $295 \mathrm{aA}$ & $10 \mathrm{aA}$ & $0.14 \mathrm{bA}$ & $0.47 \mathrm{aB}$ \\
\hline Castor bean + pigeon pea & $217 \mathrm{bA}$ & $10 \mathrm{aA}$ & $0.14 \mathrm{bA}$ & $0.64 \mathrm{aA}$ & $202 \mathrm{cA}$ & $9 \mathrm{bA}$ & $0.14 \mathrm{bA}$ & $0.69 \mathrm{aA}$ \\
\hline Castor bean + corn & $169 \mathrm{cB}$ & $10 \mathrm{aA}$ & $0.17 \mathrm{aA}$ & $1.00 \mathrm{aA}$ & $261 \mathrm{bA}$ & $11 \mathrm{aA}$ & $0.13 \mathrm{bB}$ & $0.50 \mathrm{aB}$ \\
\hline Castor bean + gliricidia & $184 \mathrm{cB}$ & $11 \mathrm{aA}$ & $0.17 \mathrm{aA}$ & $0.92 \mathrm{aA}$ & $284 \mathrm{aA}$ & $12 \mathrm{aA}$ & $0.15 \mathrm{aB}$ & $0.53 \mathrm{aB}$ \\
\hline
\end{tabular}

Note. Means followed by the same letter, lowercase in columns (Scott-Knott test) comparing intercropping systems and uppercase in rows (Tukey test) comparing tillage systems, for each variable and layer separately, do not differ significantly at $5 \%$ probability.

In the $0-10 \mathrm{~cm}$ layer, for soil tillage with subsoiling, the highest MB-C contents were found in the intercropping system with castor bean + castor bean cake. In the 10-30 cm layer, highest MB-C values were found in the intercropping systems with castor bean + castor bean cake, castor bean + common bean and castor bean + gliricidia.

The interaction between soil tillage and intercropping systems was significant for the MB-N contents in the 0-0.10 and 10-30 cm layers (Table 3). The intercropping system with castor bean under monoculture and soil tillage with plowing and harrowing (control) led to the lowest MB-N at the studied depths. Soil tillage with subsoiling, at the $0-10 \mathrm{~cm}$, resulted in highest MB-N in the systems with castor bean + gliricidia and castor bean + pigeon pea.

All intercropping systems showed higher MB-N contents than the control (castor bean in monoculture and soil tillage with plowing and harrowing) at the studied depths, which can be due to the effect of management, because of the greater supply of organic residues. The effects were more pronounced in the systems with castor bean + gliricidia for soil tillage with subsoiling in the layers of 0-10 cm and 10-30 cm, where MB-N contents were 15 and $12 \mathrm{mg} \mathrm{kg}^{-1}$, respectively.

Microbial activity, measured as evolved $\mathrm{CO}_{2}$, varied from $0.11 \mathrm{mg} \mathrm{C}-\mathrm{CO}_{2} \mathrm{~kg}^{-1}$ for castor bean + common bean and castor bean + gliricidia at $0-10 \mathrm{~cm}$ depth to $0.17 \mathrm{mg} \mathrm{C}-\mathrm{CO}_{2} \mathrm{~kg}^{-1}$ for castor bean + corn and castor bean + gliricidia at 10-30 $\mathrm{cm}$ depth for soil tillage with plowing + harrowing (Table 4).

In spite of statistical differences, amounts of released $\mathrm{CO}_{2}-\mathrm{C}$ between plowing harrowing and subsoiling systems regarding to the different intercropping systems were quite similar, especially in the 10-30 cm layer (Table 3).In turn, the lowest values of SBR occurred in the castor bean + gliricidia, castor bean and castor bean + castor bean cake systems.

The intercropping castor bean + corn under soil tillage with plowing + harrowing led to the highest $q \mathrm{CO}_{2}$ in the $0.0-10 \mathrm{~cm}$ layer (Table 4). There was no significant effect of the intercropping systems on the $q \mathrm{CO}_{2}$ for both soil layers when subsoiling was adopted (Table 3 ). In the $0-10 \mathrm{~cm}$ layer, the intercropping systems with castor bean + corn and castor + castor bean cake led to higher values of $q \mathrm{CO}_{2}$ when soil tillage was performed with plowing + 
harrowing compared to the tillage with subsoiling. Higher values of $q \mathrm{CO}_{2}$ were also observed in the 10-30 $\mathrm{cm}$ layer for the systems with castor bean + common bean, castor bean + gliricidia, and castor bean + corn $($ Table 4$)$.

\section{Discussion}

In the present study, soil tillage with plow and harrow decreased MB-C contents indicating that this practice contributes to reducing the magnitude (and possibly the diversity) of soil microbial biomass, with large impact on the edaphic microbiota. Similar trend was observed by Cunha et al. (2011) who found that conventional soil tillage with plowing + harrowing led to lower microbial-C content compared to no-tillage system in the Brazilian Cerrado, indicating that soil turning damages microbial cells and consequently reduces the $\mathrm{C}$ content of the microbial biomass. On the other hand, subsoiling management because of less soil disturbance led to increase of MB-C and decrease SBR and $q \mathrm{CO}_{2}$, suggesting higher sustainability of the agricultural system.

In intensive soil tillage management, macro-aggregates are rapidly broken, making the occluded soil organic matter (initially physically protected) more vulnerable to decomposition and mineralization (Simansky et al., 2013). This factor temporarily stimulate the microbiota to degrade soil organic matter, however, MB-C contents decrease rapidly with further depletion of the soil organic C (Lisboa et al., 2012).

To obtain reference values for the microbiological quality of the agricultural field, Lopes et al. (2013) elaborated different levels of interpretation of bioindicators for clayey Red Latosols of the Cerrado region, in the $0-10 \mathrm{~cm}$ layer, based on the organic matter content of the soil. Considering the minimum value of $205 \mathrm{mg} \mathrm{C} \mathrm{kg}^{-1}$ of soil based on the organic matter content proposed by these authors, the values of Cmic in the present study were considered as low in the system with castor bean + corn under tillage with plowing and harrowing, and classified as moderate (Cmic 206-405 mg of $\mathrm{C} \mathrm{kg}^{-1}$ of soil) in the other systems. For Lopes et al. (2013), this "low" value of microbial indicators can be a sign that inadequate management practices are being used

The results of the present study provide evidence that interaction between soil tillage with subsoiling and intercropping system with castor bean + castor bean cake has higher potential for microbial-C accumulation than the other evaluated systems. Ferreira et al. (2011) stated that management systems which promote less disturbance to soil microbial biomass have great stability, contributing to increase sustainability of the agricultural system. Lopes et al. (2012) evaluated a Tb eutrophic Haplic Cambisol in the Caatinga biome and observed that microbial-C increased in the superficial soil layers regardless of the years of intercropping because of the greater availability of organic matter, water and nutrients.

During prolonged drought periods, very common in the Irecê Plateau, Gliricidia sepium was the only specie that remained green after a water deficit period lasting from 2014 to 2017 . However, we found that spacing of planting used in the present study, one row planted in the interrows of castor bean with $1.20 \mathrm{~m}$ between plants, seems not to be adequate to intercrop gliricidia with castor bean in the semi-arid region. New studies should be conducted to test the most adequate spacing for this intercropping, since this leguminous species, besides its resistance to drought and $\mathrm{N}$ fixation symbiotically, provides shade for animals, reducing stress and promoting thermal comfort, and serves as feed for cattle due to its high protein content.

The results of MB-N should be carefully interpreted, since a high biological activity may result from consumption of labile $\mathrm{C}$ and $\mathrm{N}$ pools, or due to oxidation of organic matter from the breakdown of aggregates by anthropic action, or even from the momentary addition of organic residues. Thus, high MB-N contents may indicate both a situation of disturbance and high productivity of the ecosystem (Islam \& Weil, 2000).

Higher SBR values in the intercropping of castor bean + corn under soil tillage with plowing + harrowing can be related to the disturbances caused on soil microbial biomass. The results of $q \mathrm{CO}_{2}$ evaluating this system showed that microbial biomass was less efficient at using organic compounds, releasing more $\mathrm{C}$ in the form of $\mathrm{CO}_{2}$ and incorporating less $\mathrm{C}$ to microbial tissues, especially in the $0-10 \mathrm{~cm}$ layer.

In general, plowing and harrowing treatments presented higher values of $q \mathrm{CO}_{2}$ and SBR, which suggests greater loss of soil organic carbon compared to subsoiling management. This fact can be attributed to soil turning, which favors the oxidation of soil organic matter, increasing the release of $\mathrm{CO}_{2}$ to the atmosphere.

According to Islam and Weil (2000), SBR rates per si may not reflect an effect of soil disturbance. Instead, this variable should be preferentially related to $q \mathrm{CO}_{2}$ values in order to obtain a more realistic diagnostic of soil environment. When $q \mathrm{CO}_{2}$ is high, microorganisms are converting less soil organic $\mathrm{C}$ into microbial-C, which indicates a stress condition. According to Cunha et al. (2011), when microbial biomass becomes more efficient, less $\mathrm{CO}_{2}$ is lost to the atmosphere and higher $\mathrm{C}$ rate is incorporated to microbial biomass, resulting in lower values of $q \mathrm{CO}_{2}$. 
Management systems in which soil microbial community is less disturbed there is great stability, contributing to higher sustainability (Ferreria et al., 2011). Based on the results observed for the attributes of the microbial biomass, it can be inferred that, compared to soil tillage with plowing + harrowing, soil tillage with subsoiling caused lower disturbance in soil microbial biomass, leading to higher values of Cmic, which possibly results in greater sustainability of the agricultural activity.

\section{Conclusions}

The different soil management systems influenced microbial biomass and activity, and the most favorable conditions for soil microbiota occurred in the soil tillage system with subsoiling.

In the semi - arid condition, at 0-10 cm depth, the castor bean + castor bean crop system promoted an increase in the Cmic content, and the castor + gliriccide system increased in the Nmic content, both under soil preparation with subsoiling

\section{References}

Alves, T. D. S., Campos, L. L., Elias Neto, N., Matsuoka, M., \& Loureiro, M. F. (2011). Biomassa e atividade microbiana de solo sob vegetação nativa e diferentes sistemas de manejos. Acta Scientiarum. Agronomy, 33(2). https://doi.org/10.4025/actasciagron.v33i2.4841

Anderson, J. P. E., \& Domsch, K. H. (1980). Quantities of plant nutrients in the microbial biomass of selected soils, Soil Sci., 130, 211-216. https://doi.org/10.1097/00010694-198010000-00008

Anderson, T. H., \& Domsch, K. H. (1993). The metabolic quotient for $\mathrm{CO}_{2}\left(\mathrm{qCO}_{2}\right)$ as a specific activity parameter to assess the effect of environmental condition, such as $\mathrm{pH}$ on the microbial biomass of forest soils. Soil Biology and Biochemistry, 23(3), 393-395. https://doi.org/10.1016/0038-0717(93)90140-7

Brookes, P. C., Landman, A., Pruden, G., \& Jenkinson, D. S. (1985). Chloroform fumigation and the release of soil nitrogen: A rapid direct extraction method for measuring microbial biomass nitrogen in soil. Soil Biol. Biochem., 17, 837-842. https://doi.org/10.1016/0038-0717(85)90144-0

Cunha, E. D. Q., Stone, L. F., Ferreira, E. P. D. B., Didonet, A. D., Moreira, J. A. A., \& Leandro, W. M. (2011). Sistemas de preparo do solo e culturas de cobertura na produção orgânica de feijão e milho: II-atributos biológicos do solo. Revista Brasileira de Ciência do Solo, 35, 603-611. https://doi.org/10.1590/S010006832011000200029

Ferreira, E. P. B., Wendland, A., \& Didonet, A. D. (2011) Microbial biomass and enzyme activity of a Cerrado Oxisol under agroecological production system. Bragantia, 70(4), 1-9. https://doi.org/10.1590/S0006-87052 011000400024

Foth, H. D., \& Ellis, B. G. (1996). Soil fertility (2nd ed., p. 290). Boca Raton, Lewis Publishers.

Freire, E. C., Lima, E. F., Andrade, F. P., Milani, M., Nóbrega, M. B. M. (2007). Melhoramento genético. In D. M. P. Azevedo, \& N. E. M. O. Beltrão (Eds.), Agronegócio da mamona no Brasil (pp. 167-194). Brasília: Embrapa.

IBGE. (2016). Produção agrícola municipal, bancos de dados agregados: Sistema IBGE de recuperação automática: SIDRA. Rio de Janeiro, Brazil. Retrieved from http://www.ibge.gov.br

Islam, K. R., \& Weil, R. R. (1998). Microwave irradiation of soil for routine measurement of microbial biomass carbon. Biol. Fert. Soils, 27, 408-416. https://doi.org/10.1007/s003740050451

Islam, K. R., \& Weil, R. R. (2000). Land use effects on soil quality in a tropical forest ecosystem of Bangladesh. Agriculture Ecosystems and Environment, 79(1), 9-16. https://doi.org/10.1016/S0167-8809(99)00145-0

Lisboa, B. B., Vargas, L. K., Silveira, A. O. D., Martins, A. F., Selbach, P. A. (2012). Indicadores microbianos de qualidade do solo em diferentes sistemas de manejo. Revista Brasileira de Ciência do Solo, 36(1), 33-43. https://doi.org/10.1590/S0100-06832012000100004

Lopes, A. A. de C., Sousa, D. M. G. de, Chaer, G. M., Reis Junior, F. B. dos, Goedert, W. J., \& Mendes, I. de C. (2013a). Interpretation of microbial soil indicators as a function of crop yield and organic carbon. Soil Science Society of America Journal, 77(2), 461-472. https://doi.org/10.2136/sssaj2012.0191

Marumoto, T., Anderson, J. P. E., \& Domsch, K. H. (1982). Mineralization of nutrients from soil microbial biomass. Soil Biol. Biochem., 14, 469-475. https://doi.org/10.1016/0038-0717(82)90106-7

Mendonça, E. D. S., \& Matos, E. D. S. (2005). Matéria Orgânica do solo: Métodos de análises. Viçosa: UFV. 
Roboredo, D., Maia, J. C. de S., Oliveira, O. J., \& Roque, C. G. (2010). Uso de dois penetrômetros na avaliação da resistência mecânica de um latossolo vermelho distrófico. Engenharia Agrícola, 30(2), $307-314$. https://doi.org/10.1590/S0100-69162010000200013

Simansky, V., Bajcan, D., \& Ducsay, L. (2013). The effect of organic matter on aggregation under different soil management practices in a vine yard in an extremely humid year. Catena, 101, 108-113. https://doi.org/ 10.1016/j.catena.2012.10.011

Sparling, G. P., \& West, A. W. (1988). A direct extraction method to estimate soil microbial C: Calibration in situ using microbial respiration and 14C labelled cells. Soil Biology and Biochemistry, 20, 337-343. https://doi.org/10.1016/0038-0717(88)90014-4

Tedesco, M. J., Gianello, G., Bissani, C. A., Bohnen, H., \& Volkweis, S. I. (1995). Análise de solo, plantas e outros materiais (2nd ed., p. 174). Porto Alegre, Universidade Federal do Rio Grande do Sul.

\section{Copyrights}

Copyright for this article is retained by the author(s), with first publication rights granted to the journal.

This is an open-access article distributed under the terms and conditions of the Creative Commons Attribution license (http://creativecommons.org/licenses/by/4.0/). 